\title{
How Do We Educate Future Innovation Managers? Insights on Innovation Education in MBA Syllabi
}

\author{
Dr. Selen Kars-Unluoglu ${ }^{1}$
}

Innovation education is regarded a critical area in most business schools. This growing importance is partly a strategic response to managing in knowledge-driven competitive environment. Given the expansion in popularity of innovation courses, it is surprising that little is known about the content and process of innovation education. This paper reports on the results of an exploratory study aiming to establish what is taught and how it is taught in innovation courses. This involves analysis of course syllabi of 29 innovation courses at 20 top-ranked business schools. Results revealed that although there is a consensus on the process of innovation education, shying away from traditional didactic approaches toward a more explorative and experiential mode, there exists substantial variation in course content. While this is not indicative of the quality of individual courses, it suggests that members of innovation community run very dissimilar courses in their teaching practice. A common motif was found around multidisciplinarity and balanced coverage of static and dynamic components of innovation. Implications of findings for innovation teaching, pedagogy and curriculum development are discussed and benchmarks developed for evaluating existing curricula by instructors.

Keywords: Innovation education, Educational benchmarking, Teaching and learning, Syllabus analysis, Curriculum design

\footnotetext{
${ }^{1}$ Lecturer in Organisation Studies, Bristol Business School, University of the West of England e-mail: $\underline{\text { selen.kars@uwe.ac.uk }}$
} 


\section{Introduction}

Innovation has emerged over the last two decades as arguably the most potent economic force the work has ever experienced (Florida, 2002). The capability to create and manage innovation is essential for sustainable competitive advantage of companies and industries and therefore for the economic development of nations (Fagerberg, Mowery \& Nelson, 2005). With that expansion has come a growth in the field of innovation education. In an attempt to meet corporate world's demand for innovation managers, who recognise the forces shaping business environment, understand dynamics of innovation and are capable of innovating (AACSB, 2010), academic institutions including business schools have focused their efforts on education in innovation at all levels.

In the midst of this expansion remains the challenge of designing the content and process of such education that would best support knowledge and skills managers must possess to successfully practice and manage innovation. Unlike established business disciplines such as marketing, finance and strategic management, there is no consensus to teaching innovation (Cousens et al, 2009). Although the importance of effective innovation teaching has been recognised, it is not a topic that has been widely researched (Cousens, Goffin, Mitchell, van der Hoven \& Szwejczewski, 2009).

This study explores issues relating to the content and process of innovation education in the context of top-tier MBA programs. Understanding of these issues is not only essential for the development of curriculum, but also for the development of the field (Yıldırım \& Așkun, 2012). A detailed analysis of innovation teaching will also be useful to faculty who teach innovation, particularly those who are designing and redesigning courses and subsequently looking for ideas. 
The paper aims to provide benchmarks against which instructors can compare and develop their curricula, reflect on and improve pedagogy and teaching practices. The next section provides discussion of issues in innovation education relevant to the changing business environment and implications for educators. The research aims and methods are then outlined, followed by the presentation and discussion of research findings. Finally, conclusions and recommendations are drawn, the limitations of the research discussed and suggestions given for future research.

\section{Teaching Innovation at University}

A new economic school of thought, New Growth Theory, has emerged arguing that economic growth results from innovation (Cortright, 2001) in today's creative economy (Florida, 2002; Howkins, 2001). At organisational level, implications are clear: more innovative firms tend to be more profitable than less innovative firms (McGregor, 2007) and consequently innovation is now a top strategic priority for many companies (BCG, 2014). At individual level, Florida (2002) noted that human creativity is 'the defining feature of economic life' (p. 21) and as a consequence, innovation related activities are emerging as a significant part of many jobs. The key task for educators is to prepare individuals to participate creatively in the economy (OECD, 2000) and devise effective ways to teach the practice and management of innovation (Coomber, 2008).

Yet, the content domain and pedagogy of such education is contested (Cousens et al, 2009) and innovation instructors may need guidance in these issues for several reasons. First, the vast majority of scholars who conduct innovation research also have significant teaching commitments, but few of them have received doctoral training in the pedagogy of teaching 
innovation. Moreover, it is safe to assume that many of them did not received adequate training in the practice and management of innovation during their doctoral studies.

The consequence of these became more important when the nature of innovation as a subject discipline is considered. First, innovation is not a mono-discipline but a complex multidisciplinary subject (Goffin \&Visscher 2009; Krishnan \&Ulrich, 2001; Ulrich \& Eppinger, 1992). There is a myriad of theoretical frameworks, methods, tools and case studies offered from several disciplines that instructors can draw upon while designing their curriculum. Given the mixture in this mostly disconnected body of knowledge, instructors need insight to untangle useful theories and practices from relatively less useful ones (Liyanage \& Poon, 2002) when it comes to teaching innovation and to decide which of these can best build and support the required skills and abilities in their students.

Second, this complexity is exacerbated by the fact that innovation is a contextual subject. Like many other business disciplines there are no laws and unambiguous perspectives on the issues under consideration (Groeneveld, 2006 cited in Smulders, 2011). An example regards the involvement of customers in the front end of innovation. Some scholars suggest involving customers at the very early phases of innovation process increases speed, decreases need for costly reiterations and enhances product value (Ritter and Walter, 2003; Von Hippel \& Tyre, 1995). On the other hand, scholars like Christensen \& Bower (1996) argue that listening to customers is dysfunctional for breakthrough innovation. Bridging the two contradictory statements, Leonard \& Rayport (1997) and Ulwick (2002) argue that the key is not listening what customers say but discerning unspoken desires from the voice of customer. Such a contextual process requires lots of balancing acts in teaching practice with many theories that are not definite and robust enough (Smulders, 2011). 
With complications discussed above, personal preference and psychological comfort often interferes with course design and delivery. In the face of lack of agreement on components of a good innovation curriculum, courses are designed and conducted based on instructors' interpretations about what content should be taught and how to teach it (Mallick \& Chaudhury, 2000). In the absence of a successful model on innovation education, it is not clear whether current education build and support the key skills and abilities that innovators possess (Björklund \& Eloranta, 2008). This is a central concern especially for graduate programs of business schools (Barr \& Harris, 1997; Boyatzis, Cowen \& Kolb 1995) since 'the value of an MBA program is directly related to its basis in reality' (Maglitta, 1995, p. 122) with students and recruiters glorifying business schools that offer practical education (Gioia \& Corley 2002).

Although the importance of effective innovation teaching has been recognised, it is not a topic targeted by systematic scholarly inquiry (Goffin \& Visscher, 2009). The existing literature can be divided into two categories. Some scholars have provided insights into the design of single exemplary courses (Athaide \& Desai, 2005; Cardozo et al., 2002; Eppinger \& Kressy, 2002; Lovejoy \& Srinivasan 2002; Martinsuo, 2009; Ulrich \& Eppinger, 1992). Others have introduced specific tools and methods of instructions and their underlying pedagogy (Campbell \& Helleloid, 2002; Coughlan \& Graham, 2009; Cousens, 2009; Goffin \& Mitchell 2006; Smulders 2011). However, there are very few studies that have examined multiple innovation courses. Scholars have carried out similar research for other related disciplines, such as entrepreneurship, new product development and technology management (e.g. Fixson, 2009; Klandt, 2004; Mallick \& Chaudhury, 2000), yet insights in terms of teaching practice are not directly transferable to innovation courses. 
As there is a significant gap in understanding the current status of innovation education, it is appropriate to examine the content and process of such teaching at business schools and investigate patterns and characteristics. This is an important first step in establishing a common understanding of what subject orientation, topics, assessment methods, and teaching and learning strategies are appropriate for innovation education. Important insights can be gained by comparing teaching at different business schools, and consequently benchmarks can be developed for teaching practice. It is hoped that this study will help instructors to critically consider the way innovation is taught in their schools and explore areas of curriculum requiring improvement.

\section{Research Design}

\subsection{Data Sample}

This research is an exploratory investigation of how innovation is taught at business schools. A purposive sample was selected according to two criteria. First, schools which received high ratings in publicised league tables were chosen. The assumption was that these schools might act as trendsetters with certain emergent practices for teaching innovation, and that these practices are likely to serve the creation of a model for innovation education by affecting, today or in the future, many other schools emulating them as was the case with, for instance, case method teaching and flipped classroom (both developed in Harvard University). Second, the focus was on MBA programs rather than undergraduate or other graduate degrees since one of their primary objective is to prepare students to be managers (Boyatzis, Stubbs \& Taylor, 2002; Gosling and 
Mintzberg, 2004). Hence, the data sample was defined as required and elective courses in fulltime MBA programs of world's top business schools as ranked by publicised league tables.

Three major data sources for MBA rankings are Business Week and US News \& World Report for US business schools and The Financial Times as the key provider of multi-country ranking which all lead to well-publicised work (Baden-Fuller, Ravazzoloi \& Schweizer, 2000). US News \& World Report has a second league table which world's best universities are ranked. Even though this does not exclusively focus on business schools, it is still included for having more non-US universities in the sample.

2013 rankings of 'Financial Times Global MBA Ranking', 'Top Business School Rankings' prepared by Business Week and US News \& World Report's 'Best Business Schools 2014,2 and 'World's Best Universities' were collated. Top-25 business schools in each table were listed, duplicates were removed and 50 universities were identified. Since four of these do not offer fulltime MBA programs; the ultimate sample size is 46 of which 28 located in US, 6 in UK, 3 in Spain, 2 France, 2 in Canada and 3 in Asia.

At the second step, elective and required innovation courses offered to full-time MBA students in these 46 business schools were located through web search. A database comprising 72 innovation-related courses was developed, that includes respective instructor information

\footnotetext{
${ }^{2}$ The data for Best Business Schools 2014 is collected and published in 2013. In order to achieve parallelism in terms of ranking year 'Best Business Schools 2014' list is used.
} 


\subsection{Data Collection}

The main vehicle for data collection was course syllabi. Syllabi reveal structure, content and perspective of the courses being taught, even if they do not fully reflect real-life instruction. They enumerate what topics instructors will cover and what students will read. Previous research shows that the manner in which instructors design their courses has a significant impact on what students learn in MBA programs (Singley \& Anderson, 1989 cited in Mallick \& Chaudhury, 2002) and students learn what professors intend to teach (Boyatzis, 1991). Since the syllabi are shared by the instructors as an official position of their intent for the upcoming term they are a reliable data source for what instructors consider to be important for students to learn.

In October 2013, instructors were sent a request by e-mail for the most recent syllabus of their course promising anonymity. Follow-up e-mails were sent a month later. As a result, 29 syllabi were collected from 20 business schools worldwide. 21 were received from U.S., 3 from U.K., 2 from Singapore, and 1 each from Australia and Switzerland. While not comprehensive, the sample provides a snapshot on the way innovation is taught to future managers in different parts of the world. Participating business schools are listed in Appendix I. Supported by qualitative content analysis of web profiles of instructors to get an idea about their background and expertise this created a rich data set.

\subsection{Data Analysis}

The syllabi were analysed using content analysis (Weber, 1990). Several spreadsheets were created containing institutional and instructor features, assigned books and articles, as well as cases that were associated with each syllabus, including publisher information. I also coded the 
ways in which student learning was assessed and separate data points were created for grade allocation for each assessment method.

To reap the reliability benefits of computerised text analysis (Duriau, Reger \& Pfarrer, 2007) syllabi were imported into NVivo10. Qualitative coding of syllabus was deemed as an appropriate method suited to their non-standard nature ${ }^{3}$ instead simple word counts. First, I gauged the emphasis of each session via a process of open coding by sweeping through a total of 320-pages of syllabi and assigning teaching plans for each week (including required readings, and case material for that week) to topical categories. The process resembled what Richards (2009) calls 'topic coding' when dealing with common innovation topics such as open innovation, stage-gate process, design thinking. Though, almost all instructors were covering at least one unfamiliar topic (e.g. quantified self, market busting strategies); in such cases 'in vivo coding' (Strauss \& Corbin, 1990) was carried out to capture such 'indigenous categories' (Patton, 1990). At the second step, hierarchical axial coding was performed to sort the open codes under superordinate categories such as commercialisation issues, managerial aspects of innovation. This produced a list of 137 topics clustered in 28 content areas (first-order categories). A full list of topics and the number of courses that teach each can be found in Appendix II.

\section{Emerging Models of Innovation Education}

What should be taught within a vast range of topic choices? How to design what might be taught? What process is required to deliver the content in the classroom considering the influence of process on efficiency and effectiveness of a course (Mallick \& Chaudhury 2000)? What teaching

\footnotetext{
${ }^{3}$ Some syllabi did not include any information regarding the topic of each weeks lecture, instead would simply list the required readings. And many more would use different titles in their weekly plan for same or similar topics.
} 
methods are most suitable to integrate theory with practice? Content analysis of syllabi offers us a way forward in dealing with these grim questions while reflecting on our own teaching practice for innovation education.

\subsection{Content Areas}

Thematic analysis shows that some topics are taught in majority of courses. Most authors agree on the importance of customer-centricity for innovation success (e.g., Kim \& Wilemon, 2002; Reid \& deBrentani 2004) and hence it is not surprising to see that design thinking is a topic taught in 17 courses. Similarly, given the recognition of the distributed nature of innovation, open innovation is another widely-taught topic with 17 courses. 14 courses include discontinuous innovation and the concept of technological discontinuity, and 10 courses cover diffusion of innovation and emergence of dominant design - totalling to 18 courses that include a macro discussion of innovation, exploring its cyclical pattern of creative destruction. There are 18 courses covering managerial aspects of innovation, and there seems to be equal attention given to 'hard' issues like portfolio approaches and measurement and monitoring as well as more 'soft' issues around leadership, organisational culture and innovative climate.

Some topics are only taught at few courses. For instance, only two courses explore globalisation and its consequences for innovation, even though it is becoming a more prominent issue in business environment. Similarly, only two courses cover intrapreneurship. There are a couple of more courses that look at innovation in large companies, so it might be possible that those instructors discuss intrapreneurship in those sessions but it is still not a topic commonly taught. Only one course introduces crafting an exit strategy, though it should be noted that it probably makes up a small aspect of the course since only one article is assigned for this. 
Table 1 shows the number of courses teaching each topic area.

\section{TABLE 1 NEAR HERE}

The table also indicates that, overall, instructors are putting equal weight to the practical and applied components of the act of innovating and managing innovation as well as the theoretical domain. Topics like business model canvas, design thinking, stage-gate approaches, portfolio management and creative thinking skills require students to get acquainted with the fundamental principles of practicing innovation (methodologies, tools and techniques around it) and how to apply them in real-life situations. But to transcend vocational specifics, apart from teaching innovation, education includes teaching about innovation - its meta-aspects; its theory, its effects and the way other phenomena (organisational, social, economic etc.) impact on innovation. Topics like diffusion of innovation, S-curve model, cycles of innovation and its economic aspects are more concerned with transferring content knowledge.

Overall, there seems to be relatively little agreement on what topics to include in a course on innovation. Yet, there is a balanced coverage of 'hard' and 'soft' aspects of innovation management as well as cognitive learning promoted by theory-focused content knowledge and skills-based learning.

\subsection{Course Material}

One way to delve deeper into course content is to examine readings and authors assigned. While textbook used will have an influence on course content, only eight courses out of 29 use books to follow throughout the course. One instructor has recommended John Bessant's book Design in 
Business: Strategic Innovation through Design, although no specific parts have been assigned to students. The books specified as core text are presented in Table 2. It is interesting to note that only two books are what can be called traditional textbooks. Remaining ten books are general management books not primarily designed for classroom use.

\section{TABLE 2 NEAR HERE}

The instructors of the remaining 20 courses have decided not to recommend textbooks and instead relied on a compilation of readings from several book chapters and journal articles. This suggests that many instructors are not satisfied with available textbooks on the subject or they might perceive that textbooks do not contain appropriate material for postgraduate, postexperience students.

Regardless of textbook usage, all instructors also use course packets. Systematic analysis of assigned readings ${ }^{4}$ leads to some interesting observations. In 29 courses, 373 reading materials (excluding case study material) were assigned to students, including articles from scientific journals, business and news magazines, newspapers, background notes from Harvard Business School Press, alongside book chapters, webpages and blogposts. 29.1 per cent of all reading material assigned were Harvard Business Review articles; in this respect, they constituted the source most used. If other Harvard Business School Press material such as books and background notes are included this percentage rises to 34.7 .

\footnotetext{
${ }^{4}$ Only 'required readings' were tallied; 'recommended readings', 'supplementary readings', and 'suggested readings' were excluded.
} 
The most assigned reading is Huston and Sakkab’s (2006) 'Connect and Develop: Inside Procter \& Gamble's New Model for Innovation' assigned in seven different courses. The second most frequently assigned articles are Brown's (2008) 'Design Thinking' and 'The 12 Different Ways for Companies to Innovate' by Sawhney, Wolcott and Arroniz (2006). Both were assigned in five different courses.

A list of readings assigned in at least 3 courses can be found in Table 3, below. A further 24 reading materials were identified that were assigned in 2 courses. This leaves us with 270 items that have been assigned only in one course. The diversity of reading materials and the resulting thin distribution of reading materials across courses signals the variety of lenses instructors take in teaching innovation and might suggest that there is no agreement on what material would get the ideas across and aid student understanding.

TABLE 3 NEAR HERE

Clayton Christensen is the most popular author whose articles, books and book chapters are assigned 26 times in 17 different courses. His most assigned works are 'Disruptive Technologies: Catching the Wave' and 'Reinventing your Business Model' assigned in 4 and 3 courses, respectively. Other popular authors are Eric Von Hippel whose work has been assigned 14 times in 4 different courses and Henry Chesbrough with his work on open innovation assigned 13 times in 9 different courses.

An analysis of authors of assigned readings showed that students frequently read the works of leading management thinkers - as ranked by 2014 Thinkers 50 List. Of the individuals identified 
by Thinkers 50 rankings, 15 's works were assigned ${ }^{5}$ and their works have been assigned a combined total 67 times.

\subsection{Teaching Methods}

Innovation is an area where creative approaches to teaching and learning are needed (Goffin \& Visscher, 2009) to provide space for more action and experience. To this end, all instructors blended practice and theory in their instruction.

Case studies are one of the most popular teaching tools used in business schools for exploring the space between theory and direct experience/practice. Hence, it is not surprising to see 19 courses out of 29 use case studies to accompany lectures. In these 19 courses, case studies are used for between 17 per cent and 100 per cent of taught teaching sessions ${ }^{6}$, with an average usage of 62 per cent. When courses that do not use case studies for teaching purposes are included, the average drops to 38 per cent of all taught sessions. The use ranges from 0.1 cases per session to 2.5 cases per session, with an average of $0.85^{7}$.

Once again, there is high level of consistency in publishers, with 54 per cent of cases used published by Harvard Business School Press. Stanford University uses only its own case material, with all 32 cases assigned developed by Stanford faculty. IMD and Darden are other schools that use their own case material only, though it is worth mentioning that the case usage at these courses is below the average with 0.3 and 0.1 cases per session.

\footnotetext{
${ }^{5}$ The assigned leading thinkers are in an alphabetical order: Chan Kim, Clayton Christensen, Gary Hamel, Henry Chesbrough, Jeffrey Pfeffer, Julian Birkinshaw, Morten Hanse, Nirmalya Kumar, Nitin Nohria, Renée Mauborgne, Rita McGrath, Roger Martin, Rosabeth Moss Kanter, Teresa Amabile, Vijay Govindarajan.

${ }^{6}$ Taught teaching sessions are defined as sessions in which instruction takes place. As such, sessions that are used for assessment purposes in which exams or student presentations are taking place are not counted as taught teaching sessions.

${ }^{7}$ This figure is calculated based on the 19 courses in the sample which have assigned cases to the students.
} 
The diversity of materials adopted prevails when it comes to case selection as well. Out of 160 case studies, only eight cases were utilised in multiple courses. 'IDEO Product Development' (HBS-9-600-143) is the most popular case used in four courses. Other popular case companies are Apple, Cirque du Soleil and Google of which different cases (from different authors) have been utilised in three courses, each. Sometimes instructors use other material, which is not originally developed for case teaching purposes, as basis of case discussion in class. A common example of such material is 'Gunfire at Sea' a chapter in Elting Morison's book Men, Machines and Modern Times. This chapter is utilised in two different courses.

A striking feature is the recentness of the cases assigned. 67.5 per cent of cases were written or revised after 2005, with 31 per cent written or revised after 2010. Only 11 per cent of cases date pre-2000 with the oldest case being 'Johnson Wax: Enhance (A)' (HBS-9-583-046) published in 1982. Table 4 shows the cumulative percentage histogram of case material publication/revision years.

TABLE 4 NEAR HERE

To come up with a classroom substitute for experience, in addition to case teaching, 14 courses hosts a total of 62 guest speakers ranging from academics, to industry practitioners and entrepreneurs (veteran or in the formative stages of launching their new ventures). There are some examples that recalls for attention with their unique usage of guest speakers. The course at Cornell hosts 6 guest speakers who are either the founder or senior managers of case companies discussed in those sessions. The course at Carnegie-Mellon invites a total of 6 visiting 
entrepreneurs, one for each session, and builds sessions around those events, as there is neither course preparation nor lecture material planned for those weeks.

Other experiential learning methods, like online simulations, workshops and class exercises allowing students to experiment tools introduced at lectures are also utilised. Some courses have workshop sessions for design thinking, business modelling and attribute mapping. IDEO's acclaimed Deep Dive ${ }^{\circledR}$ Technique is also used for ideation workshops. The effectiveness of videos to teaching and learning is well-documented (see Berk 2009 for further discussion) and one course at Columbia Business School makes an extensive use of in-class videos, including feature films like documentaries, biographical films and TV series.

Two courses (from Kellogg and Wharton) can be differentiated from the rest of the sample with their unique approach in course delivery from an experiential learning perspective. They are designed almost like an innovation funnel with student teams experimenting with a stage-gate process through iteration, validation, implementation of their new venture idea by utilising tools/techniques introduced in the lectures on a weekly basis and preparing reflexive journals around their experiences.

The versatility and richness of teaching methods suggests that instructors are well aware of the fact that neither lectures nor case study teaching, the two methods of instruction that are popular in business schools, by themselves are effective to transmit knowledge and develop skills when it comes to teaching and learning innovation. 


\subsection{Assessments}

In order to prepare all students to participate in complex creative systems, in which they need to work collaboratively at multiple levels of organisation, instructors use group projects pervasively. Alongside with class participation, group project and its presentation are the most popular methods. Class participation and Group projects are used in 20 schools (74 per cent of the sample), while class participation is graded in 18 schools (67 per cent of the sample). On average, 41 per cent of marks are allocated to group project (with a range of 20 to 70 per cent) and 31 per cent of marks are allocated to class participation (with a range of 20 to 60 per cent).

Table 5 provides details of the frequency and marks allocated for each assessment method.

TABLE 5 NEAR HERE

It is important to note that all instructors left the group project framework quite loose and relatively unstructured as if they are preparing students to thrive under conditions of ambiguity characterising innovation. While instructors are considerably creative in developing tasks for group projects, 12 main types of project work was identified which is presented in Table 6 below:

TABLE 6 NEAR HERE 
Four courses use intra-team peer evaluations of how each member contributed to their teams' progress in calculating course grade. ${ }^{8}$ One course at Mendoza assigns 10 per cent of grades via inter-team evaluation where each team's final project and presentation is critically evaluated and graded by another team role-playing venture capitalists considering investment.

Further group tasks, other than group project, are assigned in three courses. These include weekly short presentations on a specific topic (e.g. an innovation technique, analysis of success of an innovative company, business model analysis). 19 courses use assessment methods to measure individual performance with examinations, pop quizzes, weekly individual assignments and case memos, final individual papers and personal reflexive journals. Only five courses use examinations. Two courses have in-class, closed book, written final examination, while three courses require students to complete an extensive case study write-up either performed in-class or take-home.

\subsection{Instructors}

The lay/expert debate is an ancient one and the tension between academic and practitioner sides is ever existent in business schools with pressure from internal and external actors (Clinebell \& Clinebell, 2008). The analysis of the background of instructors reveals that leading business schools have developed a hybrid model that uses aspects of clinical and academic faculty in a balanced way.

Out of 33 instructors running 29 courses, 18 are pursuing academic careers while the remaining 15 are clinical professors who are consultants, venture capitalists/angel investors, successful entrepreneurs, intrapreneurs with a track record of new business/product development in their

\footnotetext{
${ }^{8}$ It might be the case that other instructors adjust team members' grades as deemed necessary, but only four courses in the sample explicitly reserve marks for peer evaluation.
} 
corporate careers. In most cases, the clinical faculty possesses at least an MBA degree and few have $\mathrm{PhD}$ degrees or are currently enrolled in a doctoral program. It is also worth noting that these instructors have up to 10 years of teaching experience at several universities.

It is also striking to see how professionally qualified academic faculty is. When their faculty profile pages and CVs are analysed, it is observed that, out of 18 academics, only 6 are predominantly engaged traditional scholarly activity. The remaining 12 have been very actively engaged in consulting services either as part of the university's engagement with the industry or through their own consulting practice; four of them sit in the boards of several companies as advisors or members of the board and one is an active member of the entrepreneurial community supporting the local innovation ecosystem. In four courses academic faculty team up with clinical faculty or a more practice-oriented academic faculty member to go back and forth between theoretical and vocational domains and achieve balance between different aspects of innovation.

The faculty profile analyses suggest that, instructors have a rich experience base that allows them to guide students in practical ways as well as presenting theoretical models.

\section{Discussion and Recommendations}

The primary objective for the present article was to explore how innovation is taught in leading business school to reveal trends and characteristics. A secondary objective was to develop benchmarks based on inventory built from studying courses in these leading business schools.

In terms of content, there is little consensus on the topics taught in innovation courses. This might suggest the lack of shared vision among the community of innovation scholars about what a course in innovation is set to achieve (DeConinck \& Steiner, 1999; Newell, 1994). Innovation is 
a perfect example of a rapidly developing interdisciplinary field growing in diverse directions. It is a field covering issues from opportunity identification to design to commercialisation and hence calls for different skills, techniques and ways of thinking. This versatile nature of the subject area makes instructors to pick content based on personal expertise, preferences or demands placed on the course by their business school. Yet, although there are advantages to diversity, such wide variation in content suggests that we are in the formative years of pedagogical development. To avoid potential confusion in teaching practice we need a sharper definition of what a course on innovation needs to address. This requires starting a discussion of what is meant by the term 'innovation' as a construct that can be differentiated from similar constructs like creativity, technology management and entrepreneurship which also have slipped into the title of courses in the sample. Setting boundaries for a definition of innovation will help us, the community of innovation scholars, to sculpt the pedagogy of innovation courses and suggest critical knowledge and skills to practice and manage innovation.

Despite research findings are far away from proposing a template for a course on innovation, the course design in leading business schools provide valuable insights on how cognitivist and constructionist pedagogies can be built in the curriculum in a balanced way to focus as much on developing skills as transferring content knowledge. The cognitivist pedagogy associated with teaching about innovation (Hindle, 2007), can be traced in topics that concern the theories and meta-aspects of innovation as discussed in Section 4.1. Yet, as Whitehead (1967, p. 48) argues: 'Education should turn out the pupil with something he knows well and something he can do well. This intimate union of practice and theory aids both.' Hence apart from static components (Todorovic, 2007), teaching a course on innovation should go beyond building the theoretical basis. Instructors in the sample included dynamic components (Todorovic, 2007) providing space 
for more action and experience. Courses in leading business schools include topics that acquaint students with the fundamental methodologies for practicing and managing innovation and how to apply them in real-life situations. These topics ensure the curriculum embraces vocational/applied area of knowledge and practical components (Hindle, 2007). Such a teaching practice is also in line with AACSB's (2010) recommendations.

To create a deeper understanding of innovation and develop an insight of what theories and approaches to utilise when engaging with innovation in real-life settings, instructors should shy away from traditional teaching approaches that will only result in rote learning (Driscoll, 2000). The explorative and iterative nature of the innovation process lends itself to being taught in an experiential fashion (Beard \& Wilson, 2006). The teaching mode in leading business schools appears to be moving further towards a mode that is more explorative in nature and collaborative in style. Instructors in leading business schools built into the curriculum case studies, creative group projects, workshops, guest lectures and student participation revolving around the discussion of assigned material to achieve co-development of knowledge. These again emanate from the constructionist pedagogy, where the learner must create his/her own meaning and understanding and the teacher only facilitates the process (Vygotsky, 1978) by providing space for experiential, collaborative, reflective exercises in a 'flipped' classroom setting (Noer, 2012). In collaboration with the teachers, who are not 'experts' presenting robust theories in their definitive form, but 'coaches' (Newell, 1994), students discover how theories, tools and methods work, and what these can do for them. This does not mean that the course should be unstructured; on the contrary all courses in the sample maintain a hard line on assigned readings and assignments showing that the road to knowledge, even it is to be discovered by the student, is not an easy one. Such a teaching and learning mode requires built-in flexibility in the curricula 
allowing students and teachers to jointly improvise their own collective path as they build own knowledge (Sawyer, 2006). This would require instructors to stretch themselves intellectually and practically as students bring real market concerns into the classroom and demand insights. The challenge lies in balancing the abstracted general knowledge of academics with the specific knowledge and situational logic of practitioners.

Here, a note of caution for instructors can be offered regarding use of case studies for the sake of introducing experiential activities to curriculum. Even though case studies are useful to help students understand multiple issues in complex situations and develop an appreciation of real life management issues in a dialectic of discussion (Liang \& Wang, 2004), and develop necessary skills for making and implementing decisions in the real world (Banning, 2003) they cannot substitute for direct, personal encounter with the issue being investigated (McCarthy \& McCarthy, 2006). Section 4 offers a variety of other activities that immerse students in real markets, such as groups project requiring incorporation of course material to market realities and market realities to course assignment cyclically. Another issue concerns the evident dominance of Harvard Business School Press in readings and cases assigned. While its paramount reputation contributes to this popularity, it is worth asking whether these cover the full terrain of business situations. Swiercz and Ross (2003)'s narrative analyses of Harvard cases show that a bias exist in favour of rationalistic, mechanistic and executive-centric representations excluding political and contested nature of organisational reality. Instructors teaching innovation should be aware of these issues while using case studies.

Reflecting the emphasis on explorative and experiential nature of innovation, instructors tend to not to measure student performance through written examinations which are found to be a poor predictors of long term learning of course content or any subsequent performance, such as 
success at work (Gibbs \& Simpson, 2002). They rely more on creative group activities and reflexive individual tasks. Many of the assessment tools provide direct or indirect input from the industry which helps student to contextualise theories, tools and methods (Carew \& Cooper, 2008) increasing their knowledge of the challenges of innovation (Reinikainen \& Fallast, 2008) and also require students to build up experience with social processes in the context of teamwork. Scholars of innovation have discovered that innovation is rarely a solitary individual creation. Instead, creativity is deeply social; typically emerging from collaborative teams (Farrell, 2001; John-Steiner, 2000). Companies bring together collaboratively created ideas from many teams and coordinate their integration into a single product (Love \& Roper, 2009); and studies show that even small companies rarely innovate alone as they interact with customers and suppliers (Tidd \& Bessant, 2013). This suggests that instructors can aid the future work performance students by incorporating teamworking to curricular activities.

Based on teaching practices of leading business schools and existing theory some benchmarks are developed and presented in Table 7 which also reflects the discussion and recommendations above.

TABLE 7 NEAR HERE

\section{Limitations and Future Research}

As with all research, this study has limitations to be acknowledged when considering its implications. The information was obtained from syllabi, leaving open the question of how 
courses are actually taught, either in terms of depth or time allotted to the material. Although analysis of syllabi content greatly reduces social desirability in responses, one can only measure what is explicitly designated to be covered, not what was actually covered. A course syllabus is not a disembodied entity and the learning and teaching depends on the interaction of instructor, students, and classroom environment. Such contextual information was impossible to capture in the scope of this study. The study takes the course as the unit of analysis but the unit of observation was mostly the syllabus. The differences occurring between syllabi with respect to terminology and level of detail might have masked during content analysis some aspects of teaching methods adopted and might have left some topics underrepresented.

Next steps can include gathering the practices of instructors via interviews and observations, though this would face significant resource constraints regarding researcher time and travel costs. Future research can examine how faculty sell innovation to students in the classroom, and the extent to which students buy those arguments and knowledge. A great example of this type of research can be found in Sonenshein (2010) on organisational change.

Another limitation of the study is the disproportionate amount of syllabi submitted from US business schools. This was partly a consequence of the dominance of US business schools in ranking tables. Therefore, it would be very useful to replicate this study with a different sampling method to include more syllabi from European, Asia, South American, Australasian business schools, particularly given the rise of universities in these regions (Bradshaw 2011; Walsh 2011). It would also be interesting to determine whether topics, assumptions, or philosophies of US business schools are similar to those elsewhere. 
It is anticipated that scholars interested in innovation education will find the results of this study to be important and suggestive of relevant future research directions. The vast majority of us who conduct innovation research also have significant teaching commitments. However, we seldom apply rigor and systematic thinking to classroom situation. This paper calls for perceiving the classroom situation differently: as something that provide adequate grounds for research. Given the complexities of innovation teaching, the research agenda is potentially rich. Wider discussions on and deeper research into innovation teaching - particularly on the issue of what constitute a good curriculum and reflection on the teaching and learning process - is necessary to enhance the standing of the field. 


\section{References}

AACSB. (2010). Business schools on an innovation mission: Report of the AACSB International Task Force on business schools and innovation. Retrieved from:

http://www.aacsb.edu/ /media/AACSB/ Publications/research-reports/business-schools-on-aninnovation-mission.ashx

Athaide, G.A. \& Desai, H.B. (2005). Design and implementation of an interdisciplinary marketing/management course on technology and innovation management. Journal of Marketing Education, 27, 239-249.

Baden-Fuller, C., F. Ravazzoloi F., \& Schweizer, T. (2000). Making and measuring reputations: the research ranking of European business schools. Long Range Planning, 33 , 621-650.

Banning, J. (2003). The effect of the case method on tolerance for ambiguity. Journal of Management Education, 27, 556-567.

Barr, S. \& Harris, R. (1997). Incomplete education. CFO, 13, 30-39.

BCG. (2014). The most innovative companies 2014: Breaking through is hard to do. Retrieved from: https://www.bcgperspectives.com/Images/Most_Innovative _Companies_2014_Oct_2014_tcm80-174313.pdf

Beard, C. \& Wilson, J.P. (2006). Experiential learning: A best practice handbook for educators and trainers. London: Kogan Page.

Berk, R. A. (2009). Multimedia teaching with video clips: TV, Movies, Youtube, and Mtvu in the college classroom. International Journal of Technology in Teaching and Learning, 5, 1-21. 
Björklund, T. A., \& Eloranta, M. M. (2008). Fostering innovation: What can we learn from experts and expertise. Paper presented at the meeting of SEFI 36th Annual Conference, Aalborg, Denmark.

Boyatzis, R. E., Stubbs, E. C. \& Taylor, S. N. (2002). Learning cognitive and emotional intelligence competencies through graduate management education. Academy of Management Learning and Education, 1, 150-162.

Boyatzis, R. E., Cowen, S. C. \& Kolb, D. A. (1995). Innovation in professional education. San Francisco: Jossey-Bass Publisher.

Boyatzis, R.E. (1991). Gatekeepers of the enterprise: Assessing faculty intent and the student outcome. In J.D. Bigelow (Ed.), Managerial skills: Exploration in practical knowledge (pp. 90-102). Newbury Park, CA: Sage.

Bradshaw, D (2011, December 4). Continental Shift. Financial Times. Retrieved from: http://www.ft.com/intl/cms/s/2/35037704-1bad-11e1-8647-00144feabdc0.html

Campbell, K. \& Helleloid, D. (2002). An exercise to explore the future impact of new technologies. Journal of Product Innovation Management, 19, 69-80.

Cardozo, R.N., Durfee, W.K., Ardichvili, A., Adams, C., Erdman, A.G., Hoey, M., Iaizzo, P.A., Mallick, D.N., Bar-Cohen, A., Beachy, R., \& Johson, A. (2002). Experiential education in new product design and business development. Journal of Product Innovation Management, 19, 417.

Carew, A. I., \& Cooper, P. (2008). Engineering curriculum review: processes, frameworks and tools. Paper presented at the meeting of SEFI 36th Annual Conference, Aalborg, Denmark.

Christensen, C.M. \& Bower, J.L. (1996). Customer power, strategic investment and the failure of leading firms. Strategic Management Journal, 17, 197-218. 
Clinebell, S.K. \& Clinebell, J.M. (2008). The tension in business education between academic rigor and real-world relevance: The role of executive professors. Academy of Management Learning and Education, 7, 99-107.

Coomber, S. (2008, 23 January). Defining innovation is the easy part - but teaching it poses a tougher challenge. The Times, p. 13

Cortright, J. (2001). New growth theory, technology and learning: A practitioner's guide (Reviews of economic development literature and practice no. 4). Washington, DC: U.S. Economic Development Administration.

Coughlan, P. \& Graham, A. (2009). Embedding a threshold concept in teaching and learning of product development management. Creativity and Innovation Management, 18, 190-198.

Cousens, A., Goffin, K., Mitchell, R., van der Hoven, C. \& Szwejczewski, M. (2009). Teaching new product development using the 'CityCar' simulation. Creativity and Innovation Management, 18, 176-189.

DeConinck, J., \& Steiner, T. (1999). Developing an integrated finance and marketing MBA core course. Journal of Marketing Education, 21, 44-50.

Driscoll, M. P. (2000). Psychology of learning for instruction (2nd ed.). Needham Heights, MA: Allyn and Bacon.

Duriau V. J., Reger, R. K., \& Pfarrer, M. D. (2007). A content analysis of the content analysis literature in organizational studies: Research themes, data sources, and methodological refinements. Organizational Research Methods, 10, 5-34.

Eppinger, S.D. \& Kressy, M.S. (2002). Interdisciplinary product development education at MIT and RISD. Design Management Journal, 13, 58-61.

Fagerberg, J., Mowery, D. C. \& Nelson, R. R. (Eds.). (2005). Oxford Handbook of Innovation. Oxford: Oxford University Press. 
Farrell, M. P. (2001). Collaborative circles: Friendship dynamics and creative work. Chicago: University of Chicago Press.

Fixson, S. K. (2009). Teaching innovation through interdisciplinary courses and programmes in product design and development: An analysis at 16 US schools". Creativity and Innovation Management, 18, 199-208.

Florida, R. (2002). The rise of the creative class and how it's transforming work, life, community and everyday life. New York: BasicBooks.

Gibbs, G. \& Simpson, C. (2002). Does your assessment support your students' learning. Centre of Higher Education Practice: Open University. Retrieved from: http://www.open.ac.uk/fast/

Gioia, D.A. \& Corley, K.G. (2002). Being good versus looking good: Business school rankings and the Circean transformation from substance to Image. Academy of Management Learning and Education, 1, 107-120.

Goffin, K. \&Visscher, K. (2009). Editorial. Creativity and Innovation Management, 18, 143-146.

Goffin, K. \& Mitchell, R. (2006). Teaching new product development using the 'Cranfield CityCar' simulation. BizEd, 5, 42-45.

Gosling, J. \&Mintzberg, H. (2004). The education of practicing managers. MIT Sloan Management Review, 45, 19-22.

Hindle, K.G. (2007). Teaching entrepreneurship at university: From the wrong building to the right philosophy In A. Fayolle (Ed.), Handbook of Research in Entrepreneurship Education (Vol. 1, pp. 104-126). Cheltenham: Edward Elgar Publishing Ltd.

Howkins, J. (2001). The creative economy: How people make money from ideas. London: The Penguin Press.

John-Steiner, V. (2000). Creative collaboration. New York: Oxford. 
Kim, J. \& Wilemon, D. (2002). Strategic issues in managing innovation's fuzzy front end. European Journal of Innovation Management, 5, 27-39.

Klandt, H. (2004). Entrepreneurship education and research in German-speaking Europe. Academy of Management Learning \& Education, 3, 293-301.

Krishnan, V. \& Ulrich, K. T. (2001). Product development decisions: A review of the literature. Management Science, 47, 1-21.

Leonard, D. \& Rayport, J.F. (1997). Spark innovation through empathic design. Harvard Business Review, 75, 102-115.

Liang, N. \& Wang, J. (2004). Implicit mental models in teaching cases: An empirical study of popular MBA cases in the United States and China. Academy of Management Learning and Education, 3, 397-413.

Liyanage, S. \& Poon, P. S. (2002). Technology and innovation management learning in the knowledge economy: A techno-managerial approach. Journal of Management Development, $22,570-602$.

Love, J. H., \& Roper, S. (2009). Organizing innovation: Complementarities between crossfunctional teams. Technovation, 29, 192-203.

Lovejoy, W.S. \& Srinivasan, V. (2002). Ten years of experience of teaching a multi-disciplinary product development course. Journal of Product Innovation Management, 19, 32-45.

Maglitta, J. (1995, December 4). Top 25 techno-MBAs. Computer World, pp. 121-123.

Mallick, D.N. \& Chaudhury, A. (2000). Technology management education in MBA programs: a comparative study of knowledge and skill requirements. Journal of Engineering and Technology Management, 17, 153-173. 
Martinsuo, M. (2009). Teaching the fuzzy front end of innovation: Experimenting with team learning and cross-organizational integration. Creativity and Innovation Management, 18, 147-159.

McCarthy, P.R. \& McCarthy, H.M. (2006). When case studies are not enough: Integrating experiential learning into business curricula. Journal of Education for Business, 81, 201-204.

McGregor, J. (2007, May 14). 25 most innovative companies”. Business Week, pp. 52-64.

Newell, W. (1994). Designing interdisciplinary courses. New Directions for Teaching and Learning, 1994, 35-50.

Noer, M. (2012, November 19). Reeducating education”. Forbes.

OECD. (2000). Knowledge management in the learning society. Paris: OECD Publications.

Patton, M. Q. (1990).Qualitative evaluation and research methods. Thousand Oaks, CA: Sage.

Reid, S.E. \& de Brentani, U. (2004). The fuzzy front end of new product development for discontinuous innovations: A theoretical model. Journal of Product Innovation Management, $21,170-184$.

Reinikainen, M. T. \& Fallast, M. (2008). A platform for innovative entrepreneurship and European innovation education: Experiences from PDP, PIP and FLPD". Paper presented at the meeting of SEFI 36th Annual Conference, Aalborg, Denmark.

Richards, L. (2009). Handling qualitative data: A practical guide. London: Sage.

Ritter, T. \& Walter, A. (2003). Relationship-specific antecedents of customer involvement in new product development. International Journal of Technology Management, 26, 482-501.

Sawyer, R.K. (2006). Educating for innovation. Thinking Skills and Creativity, 1, 41-48.

Singley, M. K., \& Anderson, J. R. (1989). The transfer of cognitive skill. Cambridge, MA: Harvard University Press. 
Smulders, F.E. (2011). Get wet! Teaching innovation theories through experiential learning. Journal of Design Research, 9, 168- 184.

Sonenshein, S. (2010). We're changing — or are we? Untangling the role of progressive, regressive, and stability narratives during strategic change implementation". Academy of Management Journal, 53, 477-512.

Strauss, A. \& Corbin, J. (1990). Basics of qualitative research: Grounded theory procedures and techniques. Thousand Oaks, CA: Sage

Swiercz, P. M. \& Ross, K. T. (2003). Rational, human, political, and symbolic text in Harvard Business School cases: A study of structure and content. Journal of Management Education, 27, 407-430.

Tidd, J., \& Bessant, J. ( 2013). Managing innovation: Integrating technological, market and organizational change (5th ed.). Chichester: John Wiley \& Sons.

Todorovic, Z.W. (2007). The framework of static and dynamic components: An examination of entrepreneurial orientation and university ability to teach entrepreneurship. In A. Fayolle (Ed.), Handbook of Research in Entrepreneurship Education (Vol. 1, pp. 104-126). Cheltenham: Edward Elgar Publishing Ltd.

Ulrich, K.T. \& Eppinger, S.D. (1992). Educating product development leaders. Design Management Journal, 3, 47-54.

Ulwick, A.W. (2002). Turn customer input into innovation. Harvard Business Review, 80, 91-97.

Von Hippel, E. \& Tyre, M. (1995). How 'learning by doing' is done: Problem identification in novel process equipment. Research Policy, 24, 1-12.

Vygotsky, L.S. (1978). Mind and society: The development of higher mental processes. Cambridge, MA: Harvard University Press. 
Walsh, J. P. (2011). Embracing the sacred in our secular scholarly world. Academy of Management Review, 36, 215-234.

Weber, R. (1990). Basic content analysis (2nd ed.). Thousand Oaks, CA: Sage.

Whitehead, A. N. (1967). The aims of education and other essays. New York, NY: The Free Press.

Yıldırım, N. \& Aşkun, O. B. (2012). Insights on innovation and technology management curriculum in public universities in Turkey. Iktisat Issletme ve Finans, 27, 35-60. 
APPENDIX I: Business Schools in the Sample

\begin{tabular}{|c|c|c|c|c|c|c|}
\hline \multirow[b]{2}{*}{$\begin{array}{l}\text { Business School } \\
\text { (alphabetical) }\end{array}$} & \multirow[b]{2}{*}{ Country } & \multirow[b]{2}{*}{$\begin{array}{l}\text { \# of Courses } \\
\text { in the Sample }\end{array}$} & \multicolumn{4}{|c|}{ Ranking } \\
\hline & & & $\begin{array}{l}\text { Financial } \\
\text { Times }\end{array}$ & $\begin{array}{l}\text { Business } \\
\text { Week }\end{array}$ & $\begin{array}{c}\text { US News \& World } \\
\text { Report: Best Business } \\
\text { Schools }\end{array}$ & $\begin{array}{c}\text { US News \& World } \\
\text { Report: World's Best } \\
\text { Universities }\end{array}$ \\
\hline $\begin{array}{l}\text { Australian National } \\
\text { University }\end{array}$ & Australia & 1 & -- & -- & -- & 24 \\
\hline Columbia & US & 2 & 5 & 14 & 8 & 11 \\
\hline Darden (Virginia) & US & 1 & -- & 10 & 12 & -- \\
\hline $\begin{array}{l}\text { Foster (University of } \\
\text { Washington) }\end{array}$ & US & 1 & -- & -- & 23 & -- \\
\hline Haas & US & 1 & 12 & 13 & 7 & 22 \\
\hline IMD & Switzerland & 1 & 19 & -- & -- & -- \\
\hline Johnson (Cornell) & US & 1 & 24 & 7 & 16 & 14 \\
\hline Judge (Cambridge) & UK & 2 & 16 & -- & -- & 2 \\
\hline $\begin{array}{l}\text { Kellogg } \\
\text { (Northwestern) }\end{array}$ & US & 2 & 13 & 5 & 4 & -- \\
\hline $\begin{array}{l}\text { Kenan-Flagler (North } \\
\text { Carolina) }\end{array}$ & US & 1 & -- & 17 & 20 & -- \\
\hline $\begin{array}{l}\text { Mendoza (Notre } \\
\text { Dame) }\end{array}$ & US & 2 & -- & 20 & -- & -- \\
\hline $\begin{array}{l}\text { National University } \\
\text { Singapore }\end{array}$ & Singapore & 2 & -- & -- & -- & 25 \\
\hline Ross (Michigan) & US & 2 & -- & 8 & 14 & 17 \\
\hline Said (Oxford) & UK & 1 & 24 & -- & -- & 5 \\
\hline Sloan (MIT) & US & 2 & 9 & 9 & 4 & 1 \\
\hline Stanford & US & 1 & 2 & 4 & 1 & 15 \\
\hline $\begin{array}{l}\text { Tepper (Carnegie } \\
\text { Mellon) }\end{array}$ & US & 1 & -- & 11 & 19 & -- \\
\hline $\begin{array}{l}\text { Tuck (Dartmouth } \\
\text { College) }\end{array}$ & US & 1 & 16 & 12 & 9 & -- \\
\hline $\begin{array}{l}\text { Wharton } \\
\text { (Pennsylvania) }\end{array}$ & US & 2 & 3 & 3 & 3 & 12 \\
\hline Yale & US & 1 & 14 & 21 & 13 & 7 \\
\hline
\end{tabular}




\section{APPENDIX II: Full lists of course topics}

\begin{tabular}{|c|c|}
\hline TOPIC & $\begin{array}{c}\text { NUMBER OF } \\
\text { COURSES }\end{array}$ \\
\hline Barriers to Innovation & 6 \\
\hline Business Model & 13 \\
\hline Business Model Canvas & 3 \\
\hline Business Model Innovation & 10 \\
\hline Disruptive Business Model & 2 \\
\hline Value Proposition & 2 \\
\hline Commercialization Issues & 11 \\
\hline Alliance Strategy & 1 \\
\hline Branding and Marketing & 1 \\
\hline Channel Strategies & 2 \\
\hline Commercialization & 1 \\
\hline Go-to-Market & 1 \\
\hline Innovation to Execution & 6 \\
\hline Market Entry Strategies & 3 \\
\hline NPD Marketing Mix & 1 \\
\hline Revenue Model & 2 \\
\hline Sales & 1 \\
\hline Creativity and Innovation Processes & 23 \\
\hline Innovation Process & 12 \\
\hline Innovation Techniques & 1 \\
\hline Innovative Thinking Techniques & 5 \\
\hline Brainstorming & 2 \\
\hline Creative Problem Solving & 2 \\
\hline Mind Mapping & 1 \\
\hline Personas & 3 \\
\hline Secondary Research & 1 \\
\hline Opportunities for Innovation & 3 \\
\hline Opportunity Identification & 1 \\
\hline Opportunity Portfolios & 1 \\
\hline Personal Creativity & 1 \\
\hline Stage Gate Process & 1 \\
\hline Steps in "End-to-End" Innovation Process (from Invention to Execution and Dissemination) & 13 \\
\hline Design Criteria and Product Specifications & 2 \\
\hline Design Thinking \& its Principles and Methodology & 17 \\
\hline Customer Ethnography & 7 \\
\hline Customer Pain Point & 2 \\
\hline Customer-centered Innovation & 13 \\
\hline Design Thinking & 11 \\
\hline Design Thinking Methodology & 1 \\
\hline Pattern Spotting & 1 \\
\hline User Experience Journals & 1 \\
\hline Economic Aspects of Innovation & 2 \\
\hline Exit Decisions & 1 \\
\hline Experimentation and Learning & 11 \\
\hline Experimentation & 1 \\
\hline$M V P$ & 5 \\
\hline
\end{tabular}

Page 35 of 44 


\begin{tabular}{|c|c|}
\hline Probe and Learn & 2 \\
\hline Prototyping & 7 \\
\hline Globalization and its consequences for Innovation & 2 \\
\hline Emerging Economies & 2 \\
\hline Bottom of the Pyramid & 1 \\
\hline Globalization of Emerging Markets & 1 \\
\hline Globalization of $R \& D$ & 1 \\
\hline Polycentric Innovation & 1 \\
\hline Intrapreneurship & 2 \\
\hline Legal Issues & 8 \\
\hline$I P$ & 7 \\
\hline Legal Issues of New Ventures & 1 \\
\hline Managerial Aspects of Innovation & 18 \\
\hline Innovation Management & 7 \\
\hline Innovation to Execution & 6 \\
\hline Measuring Success and Failure & 10 \\
\hline Management Criteria for Effective Innovation & 2 \\
\hline Metrics to Monitor & 2 \\
\hline Portfolio Management & 4 \\
\hline Profiting from Innovation & 2 \\
\hline Project Uncertainty & 3 \\
\hline Risk of Failure & 1 \\
\hline Valuing Innovation & 1 \\
\hline Organisational Innovation & 6 \\
\hline 'People' Issues & 7 \\
\hline Culture of Innovation & 4 \\
\hline Leadership for Innovation & 2 \\
\hline Managing Creative Professionals & 1 \\
\hline Managing Creativity & 3 \\
\hline Managing $R \& D$ Team & 1 \\
\hline Nurturing Innovation & 1 \\
\hline Values and Incentives & 1 \\
\hline Market Creation & 7 \\
\hline Blue Ocean Strategy & 5 \\
\hline Market Busting Strategies & 1 \\
\hline Market Space Identification & 1 \\
\hline New Ideas Old Markets & 1 \\
\hline Market Entry Strategy & 2 \\
\hline First Mover Advantage & 1 \\
\hline Next Mover Advantage & 1 \\
\hline Market Immersion & 2 \\
\hline 'Myths' of Innovation & 4 \\
\hline Networks of Innovators & 7 \\
\hline Cross-Pollination & 1 \\
\hline Innovation Networks & 3 \\
\hline National Innovation Systems & 1 \\
\hline Networked Markets & 2 \\
\hline Open Innovation & 17 \\
\hline Communities - User Innovation & 2 \\
\hline Crowdsourcing & 2 \\
\hline
\end{tabular}

Page 36 of 44 
Lead User Method - User Innovation

Lead User Research

Motives for Open Innovation

Open Innovation

Open Source

Prizes

Toolkits - User Innovation

Triple Helix

University-Industry Technology Transfer

User Hacking

User Innovation

\section{Patterns and Cycles of Innovation}

Diffusion of Innovations

Disruptive Innovation

Dominant Design

Network Externalities

S Curve Diffusion

Technological Discontinuity

\begin{tabular}{|c|c|}
\hline $\begin{array}{l}\text { Pitching } \\
\quad \text { Idea Pitching } \\
\quad \text { Presentation Skills }\end{array}$ & $\begin{array}{l}8 \\
8 \\
2\end{array}$ \\
\hline Self & 3 \\
\hline Brain Health & 1 \\
\hline Happiness & 1 \\
\hline Healthy Living & 1 \\
\hline Quantified Self & 1 \\
\hline SMEs & 1 \\
\hline Start-Up & 12 \\
\hline Entrepreneurship & 2 \\
\hline Incumbent's Advantage & 1 \\
\hline Innovation in New Ventures & 1 \\
\hline Lean Startup & 2 \\
\hline Legal Issues of New Ventures & 1 \\
\hline New Venture Creation & 8 \\
\hline Scaling & 1 \\
\hline Social Entrepreneurship & 1 \\
\hline Strategic Aspects of Innovation & 10 \\
\hline Core Rigidities & 1 \\
\hline Dynamic Capabilities & 1 \\
\hline Exploration and Exploitation & 3 \\
\hline Innovation Capabilities & 1 \\
\hline Innovation Strategy & 3 \\
\hline Strategic Management of Innovation & 7 \\
\hline Technology and Strategy & 2 \\
\hline Types of Innovation & 13 \\
\hline Architectural Innovaton & 1 \\
\hline Organisational Innovation & 6 \\
\hline Product Innovation & 2 \\
\hline Service Innovation & 2 \\
\hline Venture Capital & 3 \\
\hline
\end{tabular}


Table 1: Course Content

\begin{tabular}{|c|c|c|c|}
\hline Topic & Details / Examples & $\begin{array}{c}\text { Number of } \\
\text { Courses }\end{array}$ & $\begin{array}{l}\text { \% of Total } \\
\text { Courses }\end{array}$ \\
\hline Managerial Aspects of Innovation & & 18 & $62 \%$ \\
\hline Measuring Success and Failure & $\begin{array}{l}\text { Valuing innovation; risk of failure; measurement criteria for effective } \\
\text { innovation and metrics to monitor; portfolio management }\end{array}$ & 10 & $34 \%$ \\
\hline 'People' Issues & $\begin{array}{l}\text { Culture; leadership; managing creative professionals and R\&D teams, use of } \\
\text { values and incentives for nurturing innovation }\end{array}$ & 9 & $31 \%$ \\
\hline Organizing for Innovation & Organisational structure and design choices & 8 & $28 \%$ \\
\hline Execution Challenges & & 7 & $24 \%$ \\
\hline Patterns and Cycles of Innovation & $\begin{array}{l}\text { Diffusion of innovations; S-curve diffusion; technological discontinuity and } \\
\text { emergence of dominant design }\end{array}$ & 18 & $62 \%$ \\
\hline $\begin{array}{l}\text { Design Thinking \& its Principles and } \\
\text { Methodology }\end{array}$ & $\begin{array}{l}\text { Customer ethnography; customer-centered innovation and customer pain- } \\
\text { points; user experience journals }\end{array}$ & 17 & $59 \%$ \\
\hline Open Innovation & $\begin{array}{l}\text { User innovation; user innovation toolkits; user hacking; leader user method; } \\
\text { crowdsourcing; open source innovation; motives for open innovation; triple } \\
\text { helix; university-industry technology transfer }\end{array}$ & 17 & $59 \%$ \\
\hline Steps in "End-to-End" Innovation Process & $\begin{array}{l}\text { Concept generation, development and testing; competition mapping; } \\
\text { forecasting; execution and dissemination }\end{array}$ & 13 & $45 \%$ \\
\hline $\begin{array}{l}\text { Business Model Canvas and Business } \\
\text { Model Innovation }\end{array}$ & & 13 & $45 \%$ \\
\hline Types of Innovation & $\begin{array}{l}\text { Architectural innovation; product innovation; service innovation; } \\
\text { organisational innovation }\end{array}$ & 13 & $45 \%$ \\
\hline New Venture Creation & $\begin{array}{l}\text { Entrepreneurship; lean start-up; scaling for new ventures; incumbent's } \\
\text { advantage }\end{array}$ & 12 & $41 \%$ \\
\hline Commercialization Issues & $\begin{array}{l}\text { Alliance strategies; channel strategies; market entry strategies and wider } \\
\text { branding, marketing, and sales issues }\end{array}$ & 11 & $38 \%$ \\
\hline Experimentation and Learning & Prototyping; minimum viable products and probe and learn & 11 & $38 \%$ \\
\hline Strategic Aspects of Innovation & $\begin{array}{l}\text { Core capabilities and core rigidities; dynamic capabilities; strategic } \\
\text { management of innovation; innovation strategy }\end{array}$ & 10 & $34 \%$ \\
\hline Idea Pitching & Presentation skills for an effective pitch & 8 & $28 \%$ \\
\hline Intellectual Property & & 7 & $24 \%$ \\
\hline Market Creation & Blue Ocean Strategy; market busting strategies; market space identification & 7 & $24 \%$ \\
\hline Networks of Innovators & National Innovation Systems and cross-pollination & 7 & $24 \%$ \\
\hline Barriers to Innovation & & 6 & $21 \%$ \\
\hline Innovative Thinking Techniques & $\begin{array}{l}\text { Brainstorming, mind mapping, use of personas and ways to enhance personal } \\
\text { creativity }\end{array}$ & 6 & $21 \%$ \\
\hline 'Myths' of Innovation & & 4 & $14 \%$ \\
\hline Stage-Gate Approaches & Structured innovation processes & 4 & $14 \%$ \\
\hline Self & Brain health, happiness and healthy living & 3 & $10 \%$ \\
\hline Venture Capital & How venture capital works & 3 & $10 \%$ \\
\hline Design Criteria and Product Specifications & & 2 & $7 \%$ \\
\hline Economic Aspects of Innovation & $\begin{array}{l}\text { A macroeconomic view on innovation and its role in growth, industry } \\
\text { structure and evolution }\end{array}$ & 2 & $7 \%$ \\
\hline $\begin{array}{l}\text { Globalization and its consequences for } \\
\text { Innovation }\end{array}$ & $\begin{array}{l}\text { Globalization of emerging economies and opportunities they offer for } \\
\text { innovation, R\&D globalization and polycentric innovation }\end{array}$ & 2 & $7 \%$ \\
\hline Intrapreneurship & & 2 & $7 \%$ \\
\hline Market Entry Strategy & First-mover advantage and next-mover advantage & 2 & $7 \%$ \\
\hline Market Immersion & & 2 & $7 \%$ \\
\hline Exit Decisions & & 1 & $3 \%$ \\
\hline
\end{tabular}


Table 2: List of Book Titles Recommended by Course Instructors

\begin{tabular}{|l|l|l|}
\hline $\begin{array}{l}\text { Authors } \\
\text { Surname) }\end{array}$ & Book Title & Publisher \\
\hline Brown & $\begin{array}{l}\text { Change by Design: How Design Thinking Transforms Organizations and Inspires } \\
\text { Innovation }\end{array}$ & Harper Collins \\
\hline Bruce \& Bessant & Design in Business: Strategic Innovation Through Design & $\begin{array}{l}\text { Pearson } \\
\text { Education }\end{array}$ \\
\hline Liedtka & Designing for Growth: A Manager's Design Thinking Toolkit & $\begin{array}{l}\text { Columbia } \\
\text { UniversityPress }\end{array}$ \\
\hline $\begin{array}{l}\text { Anthony \& } \\
\text { Christensen }\end{array}$ & Innovation Handbook: A Roadmap to Disruptive Growth & HBS Publishing \\
\hline DeGraff \& Quinn & Leading Innovation: How to Jump Start Your Organization's Growth Engine & McGraw Hill \\
\hline $\begin{array}{l}\text { McGrath \& } \\
\text { Macmillan }\end{array}$ & Market Busters: 40 Strategic Moves That Drive Exceptional Business Growth & HBS Press \\
\hline $\begin{array}{l}\text { Christensen \& } \\
\text { Anthony \& Roth }\end{array}$ & Seeing What's Next: Using Theories of Innovation to Predict Industry Change & HBS Press \\
\hline $\begin{array}{l}\text { Burgelman \& } \\
\text { Christensen \& } \\
\text { Wheelwright }\end{array}$ & Strategic Management of Technology and Innovation & McGraw Hill \\
\hline Geroski & The Evolution of New Markets & $\begin{array}{l}\text { Oxford } \\
\text { University Press }\end{array}$ \\
\hline Blank \& Dorf & $\begin{array}{l}\text { The Start-up Owner's Manual: The Step-by-Step Guide for Building a Great } \\
\text { Company }\end{array}$ & K\&S Ranch \\
\hline Roam & Unfolding the Napkin & Penguin \\
\hline Johnson & Where Good Ideas Come From: The Natural History of Innovation & Penguin \\
\hline
\end{tabular}


Table 3: Most Assigned Readings

\begin{tabular}{|c|c|c|c|}
\hline $\begin{array}{l}\text { Authors } \\
\text { (Surname) }\end{array}$ & Title & Source / Year & $\begin{array}{c}\text { Number of } \\
\text { Courses }\end{array}$ \\
\hline Hudson \& Sakkab & $\begin{array}{l}\text { Connect and Develop: Inside Procter \& Gamble's New Model } \\
\text { for Innovation }\end{array}$ & $\mathrm{HBR} / 2006$ & 7 \\
\hline Brown & Design Thinking & HBR / 2008 & 5 \\
\hline Kim \& Mauborgne & Blue Ocean Strategy & HBR / 2004 & 4 \\
\hline Bower \& Christensen & Disruptive Technologies: Catching the Wave & $\mathrm{HBR} / 1995$ & 4 \\
\hline $\begin{array}{l}\text { Sawhney \& Wolcott \& } \\
\text { Arroniz }\end{array}$ & The 12 Different Ways for Companies to Innovate & $\begin{array}{l}\text { MIT Sloan } \\
\text { Management } \\
\text { Review / } 2006\end{array}$ & 4 \\
\hline $\begin{array}{l}\text { Von Hippel \& Thomke } \\
\text { \& Sonnack }\end{array}$ & Creating Breakthroughs at $3 \mathrm{M}$ & $\mathrm{HBR} / 1999$ & 3 \\
\hline Von Hippel & $\begin{array}{l}\text { Democratizing innovation: the evolving phenomenon of user } \\
\text { innovation }\end{array}$ & $\begin{array}{l}\text { International } \\
\text { Journal of } \\
\text { Innovation } \\
\text { Science / } 2009\end{array}$ & 3 \\
\hline Gourville & $\begin{array}{l}\text { Eager Sellers and Stony Buyers: Understanding the } \\
\text { Psychology of New-Product Adoption }\end{array}$ & $\mathrm{HBR} / 2006$ & 3 \\
\hline Boudreau \& Lakhani & How to Manage Outside Innovation & $\begin{array}{l}\text { MIT Sloan } \\
\text { Management } \\
\text { Review / } 2009\end{array}$ & 3 \\
\hline Beckman \& Barry & Innovation as a Learning Process: Embedding Design Thinking & $\begin{array}{l}\text { California } \\
\text { Management } \\
\text { Review / } 2007\end{array}$ & 3 \\
\hline $\begin{array}{l}\text { Johnson \&. Christensen } \\
\text { \& Kagermann }\end{array}$ & Reinventing your Business Model & $\mathrm{HBR} / 2008$ & 3 \\
\hline Leonard \& Rayport, & Spark Innovation through Empathic Design & HBR / 1997 & 3 \\
\hline $\begin{array}{l}\text { Birkinshaw \& Bouquet } \\
\& \text { Barsoux }\end{array}$ & The 5 Myths of Innovation & $\begin{array}{l}\text { California } \\
\text { Management } \\
\text { Review / } 1999\end{array}$ & 3 \\
\hline Shapiro \& Varian & The Art of Standard Wars & $\begin{array}{l}\text { California } \\
\text { Management } \\
\text { Review / } 1999 \\
\end{array}$ & 3 \\
\hline Gladwell & The Creation Myth & $\begin{array}{l}\text { The New Yorker / } \\
2011\end{array}$ & 3 \\
\hline Chesbrough & The Era of Open Innovation & $\begin{array}{l}\text { MIT Sloan } \\
\text { Management } \\
\text { Review / 2003 }\end{array}$ & 3 \\
\hline Foster & $\begin{array}{l}\text { The S-Curve: A New Forecasting Tool } \\
\text { (Chapter in a book) }\end{array}$ & $\begin{array}{l}\text { Innovation: The } \\
\text { Attacker's } \\
\text { Advantage / } 1986\end{array}$ & 3 \\
\hline
\end{tabular}


Table 4: Distribution of case studies according to publication years (cumulative percentages)

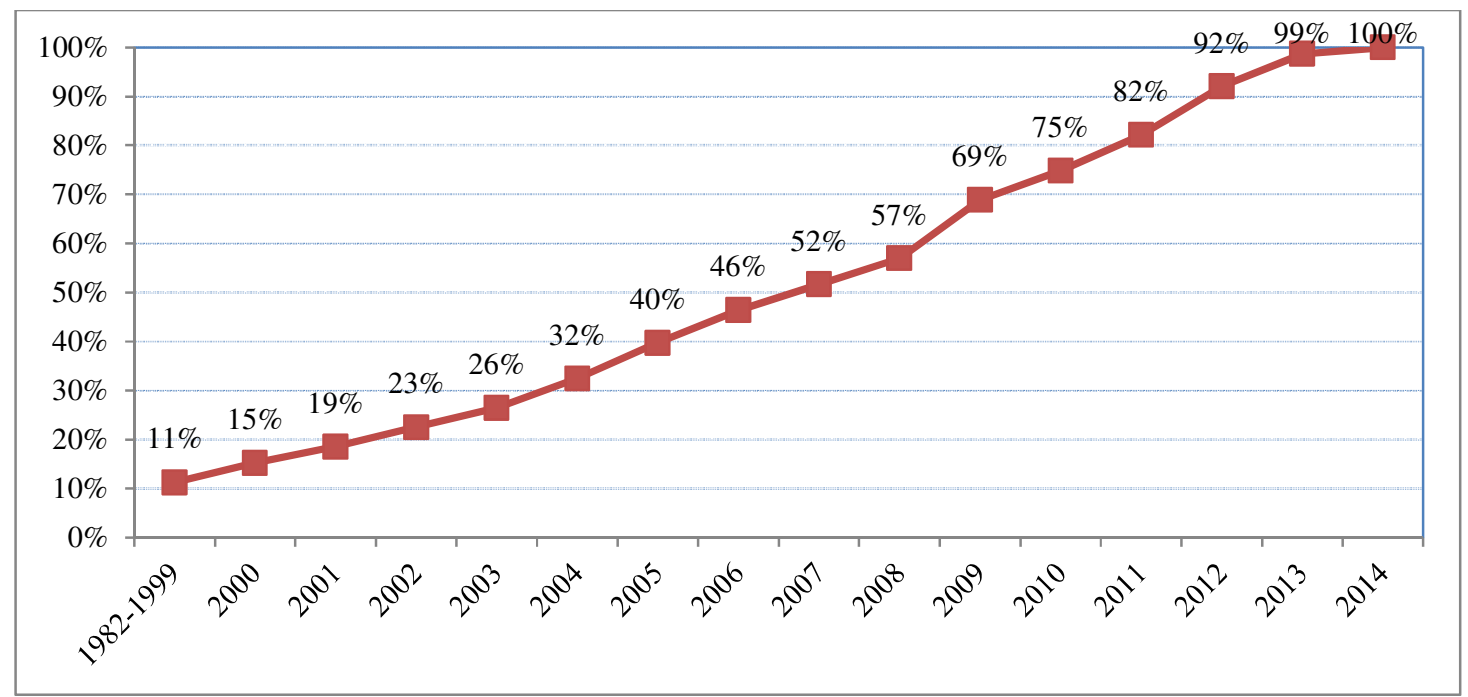


Table 5: Overview of the assessment methods used

\begin{tabular}{|l|r|r|r|}
\hline Assessment Method & $\begin{array}{l}\text { Frequency in } \\
\text { the Sample }\end{array}$ & $\begin{array}{l}\text { Average Marks } \\
\text { Allocated } \neq\end{array}$ & $\begin{array}{l}\text { Range of Marks Allocated } \\
\text { (Minimum-Maximum) } \neq\end{array}$ \\
\hline Class participation & 18 & $32 \%$ & $20-60 \%$ \\
\hline Examinations & 5 & $31 \%$ & $20-50 \%$ \\
\hline Individual paper & 10 & $47 \%$ & $10-100 \%$ \\
\hline $\begin{array}{l}\text { Individual reflexive } \\
\text { journals }\end{array}$ & 3 & $18 \%$ & $20-70 \%$ \\
\hline Group project * & 21 & $40 \%$ & $12-30 \%$ \\
\hline Group assignments ** & 3 & $21 \%$ & $10-50 \%$ \\
\hline $\begin{array}{l}\text { Group project } \\
\text { presentation *** }\end{array}$ & 9 & $30 \%$ & $5-15 \%$ \\
\hline Peer evaluation & 4 & $10 \%$ & $15-20 \%$ \\
\hline Pop quizzes & 2 & $18 \%$ & $5-30 \%$ \\
\hline $\begin{array}{l}\text { Weekly individual } \\
\text { assignments and exercises }\end{array}$ & 4 & $21 \%$ & $15-30 \%$ \\
\hline Written case assessments & & & \\
\hline
\end{tabular}

\footnotetext{
₹ The average marks and the range of marks allocated are calculated by taking into account only the courses that use that particular assessment method.

* Group project marks are collated for any group assignment that constitutes the group project as well as the final group report. Hence, it will include intermediary deliverables, progress reports, as well as the final report.

** Group assignments include all tasks that would be tackled as a group different than the final group project, including small weekly group assignments and exercises that are submitted throughout the term.

*** The data for group project presentation marks include only the syllabi in which group project presentation was separately marked - as explicitly stated by the instructor in the syllabus. It might be the case that group projects are presented in-class in the majority of the courses but when these presentations are not independently marked with no separate marks allocated in the syllabi's course assessment section no value was entered in compiling the above table.
} 
Table 6: Group projects assigned by instructors

- Industry practicum projects originated by students as potential startup opportunities that require students to undertake an innovation project that aims to deliver a breakthrough in products, services or business model starting with the articulation of the customer pain points, development of value propositions and creation of a series of hypotheses and results of concept tests;

- Industry practicum projects of interest to outside corporations identified by instructors or sponsors where student teams work with a corporate client to solve a real-life business problem;

- Design projects that put student teams in a competitive position in which they compete against each other to design, prototype, build and market a product to be presented for sale and review;

- Design projects that require student teams to design and develop a new product for the sponsors / clients;

- Innovative capabilities audit of a company chosen by students requiring them to develop their own conceptual framework to do an audit and use that audit framework to assess innovative capabilities of the company chosen;

- Analysis of an innovation related challenge, pressing business problem or opportunity faced by an organisation and development of an innovative solution based on relevant frameworks, tools and techniques;

- Consulting projects that require student teams to work closely with companies (ranging from small, high technology start-ups to established ones) looking to improve their innovation outcomes;

- Business Model Analysis of a company including any anticipated need for business model change and proposal of a new business model for the company to consider;

- Identification of an attractive market space for business model innovation including a rigorous analysis of market dynamics, value proposition and value capture to propose a novel business model in this space;

- Idea pitch for a new market space;

- Innovation assessment for the commercializability of an innovation;

- Group projects based on secondary research on any aspect of lecture material. 
Table 7: Benchmarks for innovation education

\begin{tabular}{|ll|}
\hline Curriculum Dimension & Benchmark Criteria \\
\hline Pedagogical orientation & A cyclical dance between cognitivist and constructionist pedagogies \\
\hline Subject learning objectives and content & Conceptual issues and meta-theoretical aspects \\
& $\begin{array}{l}\text { Skills development } \\
\text { 'Hard' and 'soft' aspects of innovation }\end{array}$ \\
\hline Teaching and learning strategies & Instructor as mediator/facilitator/coach \\
& Active learning and small-group, collaborative learning \\
\hline Assessment & $\begin{array}{c}\text { Innovative, collaborative and immersive assessment tasks stimulating learning } \\
\text { and understanding }\end{array}$ \\
\hline
\end{tabular}

